\title{
A study on the reuse of ash from sugarcane bagasse
}

\author{
Estudo da reutilização das cinzas do bagaço da cana-de-açúcar
}

Monique Carrer Hobold ${ }^{1}\left(\mathbb{D}\right.$, , Alex Hahn Matos ${ }^{2}$ (D), Karen Amorin da Silva ${ }^{2}$ (D), Glaucea Warmeling Duarte ${ }^{3}$

\begin{abstract}
A B S T RAC T
The generation of large amounts of ash from sugarcane bagasse by its producing countries is becoming a worldwide-problem. Its irregular application, such as in fertilizers, contaminates soil and water, causing a great environmental problem. Studies show it is possible to apply ash in some specific areas, such as replacement of portland cement, replacement of clay, as an adsorbent, in the treatment and stabilization of soils, in the pavement of road asphalt, among others. The objective of the present article is to evaluate which are the most promising areas for the use of sugarcane bagasse ash. The work was developed with a bibliographic search, using the bibliometrics technique. The results obtained show that it is possible to use ash in several different areas. However, having a detailed study of the characteristics of the ash obtained is important, because they are directly related to the regions and climates where sugarcane is cultivated, besides its granulometry, collection time the ashes in the boilers, pHs, curing time, etc. In conclusion, results can be very different for the same application area, depending on the properties of the ash obtained.
\end{abstract}

Keywords: waste recovery; soil stabilization; portland cement replacement; adsorber; red pottery.

\begin{abstract}
RE S U M 0
A geração de grandes quantidades de cinza do bagaço da cana-deaçúcar por países produtores está se tornando um problema no âmbito mundial. Sua aplicação irregular, como em fertilizantes, contamina solos e águas, ocasionando um grande problema ambiental. Estudos mostram que é possível aplicar cinzas em algumas áreas específicas como substituição do cimento Portland, substituição da argila, como adsorvente, no tratamento e estabilização de solos, na pavimentação de asfalto rodoviário, entre outros. O objetivo deste artigo é avaliar quais são as áreas mais promissoras para a utilização da cinza do bagaço da cana-de-açúcar. O trabalho foi desenvolvido por meio de uma pesquisa bibliográfica, utilizando a técnica bibliométrica. Os resultados obtidos comprovam que é possível a utilização das cinzas em várias áreas diferentes. Entretanto, para cada aplicação é importante haver um estudo detalhado das características da cinza obtida, pois estão diretamente relacionadas às regiões e climas onde a cana é cultivada, granulometrias, tempo de coleta das cinzas nas caldeiras, pHs, tempo de cura etc. Em suma, para a mesma área de aplicação, os resultados podem ser muito diferentes, dependendo das propriedades das cinzas obtidas.
\end{abstract}

Palavras-chave: valorização de resíduos; estabilização do solo; substituição de cimento portland; adsorvente; cerâmica vermelha.

\footnotetext{
${ }^{1}$ Undergraduate, Centro Universitário Barriga Verde - Orleans (SC), Brazil.

${ }^{2}$ Academic, Centro Universitário Barriga Verde - Orleans (SC), Brazil.

${ }^{3}$ Professor, Centro Universitário Barriga Verde - Orleans (SC), Brazil.

Correspondence address: Leonir Dall'Alba, 361- Bairro Murialdo- CEP: 88870-000 - Orleans (SC), Brazil - E-mail: gwduarte@gmail.com.

Conflicts of interest: the authors declare that there are no conflicts of interest.

Funding: none.

Received on: 12/05/2019. Accepted on: 04/24/2020

https://doi.org/10.5327/Z2176-947820200635
} 


\section{Introduction}

When seeking sustainable development, new approaches emerge in the chemical industry, with the concept of green chemistry, which promotes more economical and environmentally correct methodologies. Among them, there are those focused on the production of more efficient and cheaper inputs. In this way, contributing to reduce the environmental impacts of the production chain with industrial ecology, which consists of the integration of the principles of Science, Engineering and Ecology in industrial systems so that the generation of products and services provided minimize the environmental impacts and optimize the use of resources, energy and capital (VARGAS et al., 2017).

Sugarcane is grown in approximately 110 countries, with Brazil being its largest producer in the world, followed by India, China and Thailand. It is estimated that in Brazil production exceeds 600 million tons / year (FARIA; HOLANDA, 2013). The annual production of sugar cane in Brazil contributes about US \$ 43.8 billion in gross domestic product. About $80 \%$ of Brazil's biomass electricity is generated from sugarcane bagasse. However, the process of generating energy from bagasse leads to a by-product residue, sugarcane bagasse ash, which requires disposal (ANDREÃO et al., 2019).

Sugarcane production is one of the main agricultural activities in Brazil, and one of the by-products generated in sugar and ethanol producing plants is the sugarcane bagasse ash sand (SBAS) (ALMEIDA et al., 2015). As the authors Faria and Holanda (2013) add, this sugarcane bagasse is normally reused in the industry itself as a fuel source in boilers, in energy cogeneration and, as a result, an enormous amount of ash is generated throughout the world. Roughly $2.5 \%$ of the mass from the cane is transformed into ash, of which most of its reuse is in the form of fertilizers.

The sugarcane bagasse that is collected during processing has a good calorific value and is used for supplementary energy production. However, the ash generated in the process must be dumped in landfills (CHOPPERLA et al., 2019), which normally does not happen.

The ash, removed from the boilers, is usually stored in the open air when not used as a source of raw material in other processes, waiting for indefinite periods until it has a destination, usually in the crops as fertilizers (ALMEIDA et al., 2015), in the form of a mixture of vinasse (distillation remains) and bagasse ash, which can alter the physical and chemical characteristics of soil (FARIA; HOLANDA, 2013).

The use of industrial and agricultural waste in a controlled manner, such as ash from sugarcane bagasse, has been the focus of recent research due to economic, environmental, and technical issues (MOHAN; NARAYANASAMY; CHANDRASEKAR, 2018), because this by-product harms the environment when handled in an irregular way, such as the contamination of soils and water bodies (IMRAN et al., 2016).

Thus, the technically controlled use of industrial waste to replace natural resources to produce new products with comparable quality has a major economic and sustainable contribution (DAL MOLIN FILHO et al., 2019). Thus, studies that evaluate the possibilities of reusing the ash are promising, given that this material will have a more correct and profitable destination.

In addition to contributing to the conservation of the environment, by reducing waste disposal and the extraction of natural resources, it also results in minimizing costs with the final destination and management of waste, as well as economic gains with the production of materials of reduced costs (BRAGAGNOLO et al., 2018).

Studies by Joshaghani, Ramezanianpour and Rostami (2016) show that parts of the ash can be used to replace Portland cement. The proper use of bagasse ash in cement mortar can provide the ideal solution for environmental issues (REZA, 2019).

The authors Schettino and Holanda (2015a) present the use of sugarcane ash in the ceramic industry. The manufacture of bricks using waste presents better performance and low production cost, leading to a more sustainable construction (SANTHOSH; JAGAN; PRIYANGA, 2018). On the other hand, Ferreira, Fageriae and Didonet (2012) evaluate its use in soil treatment. The article by Hasan et al. (2016) made a publication for the use of ash in the road asphalt pavement.

Some papers have proved the feasibility of insertion in infrastructure works, such as in the use of materials for grounding, reinforcement for road construction and production of asphalt mixtures (BRAGAGNOLO et al., 2018).

The considerations pointed out in the literature can serve as a starting point for the development of new specific studies on the possibilities of using the ash from sugarcane bagasse in an effective and efficient manner, thus reducing the disposal of this residue in the environment.

Based on this premise, there is a need to investigate the state of the art of scientific production related to the theme, so that future studies can be grounded. Thus, the main objective of the present study is to analyze, from the point of view of bibliometric theory, the scientific productivity regarding the main uses of sugarcane ash.

\section{Methodological procedures}

Research presented in this article was developed using the procedures of a bibliographic study, with the collection of data using the bibliometrics technique, which is traditionally used in some areas to evaluate scientific research on a given topic, (SACARDO, 2012). Depending on the results obtained and the methodology used to analyze them, research can also be classified as quali-quantitative and, regarding the objectives, as descriptive research, it has the function of describing the characteristics observed in the selected papers.

The articles used for this bibliographic search were selected from three databases, namely: Science Direct, Scopus, and Web of Science. The search term used in the three cited bases was "Sugarcane bagasse ash", and a total of 488 articles were found. It is important to note that the searches were made considering articles published by December 2019. 
Of this total, 163 articles were duplicate, that is, published in more than one evaluated database, with 325 articles remaining for further research.

After applying this first filter, all titles and abstracts of the papers were evaluated to verify if they were related to the objective of the proposed article, which is to evaluate the possible applications of ash from sugarcane bagasse.

After reading the items, 102 articles were not within the context, with a total of 223 articles used for the development of this paper.

To obtain these results in the databases, research was carried out considering only the original articles. The keywords should also appear only in the title, abstract, or keywords of the articles. The articles selected for research sought to evaluate items such as year of publication, main authors, and countries of affiliation, in addition to the objectives, methods, and results of each selected article. Moreover, we sought to classify the themes discussed in the articles to make the discussion of results easier.

\section{Results and Discussion}

The articles used for the development of the present paper were classified according to their year of publication, as shown in Figure 1. It can be seen from the results presented that those papers that deal with the possible uses of sugarcane bagasse ash are relatively recent, with publication dates after 2006. In addition, there has been a significant growth over the last five years, which makes the growing concern to find a viable application visible, both economically and environmentally, for this type of by-product.
As for the countries where these publications were developed, there is a total of 22 countries, among which Brazil stands out for the number of publications with 50 articles, followed by India, with 45 articles. Figure 2 shows the countries most cited in the evaluated publications. Both Brazil and India account for approximately $70 \%$ of all papers. This can be explained by the fact that these two countries are the two largest sugar cane producers in the world (LEITE et al., 2018), leading to the generation of a large amount of ash from sugar cane bagasse and, consequently, the need to seek viable alternatives for its use.

Other pieces of information extracted were regarding the authors of each country, as well as the number of articles published by each researcher. In Brazil, among the evaluated publications, the researcher who most published papers on the topic was Holanda JNF, with 12 published articles, followed by Faria KCP, with 7 articles, Sales A., with 6 articles, and authors Akasaki JL, Melges JLP and Tashima MM, with 5 articles each. In India, the researchers who most published works on the topic were Madurwar M., with 7 articles, Ralegaonkar M., with 6 articles, Bahurudeen A., with 5 articles, and Santhanam M. with 4 articles. In the other countries with published articles on the topic, the authors participated in less than 4 papers, therefore not cited.

It is noticed that, unlike other topics, there are not many authors with large amounts of publications on the topic studied. This is indicative of the novelty of the topic in the technical and scientific world. Much of the knowledge is acquired empirically during the processing of ash, such as during its use as a fertilizer, which is developed, usually without control, by the big producers or processors of this material.

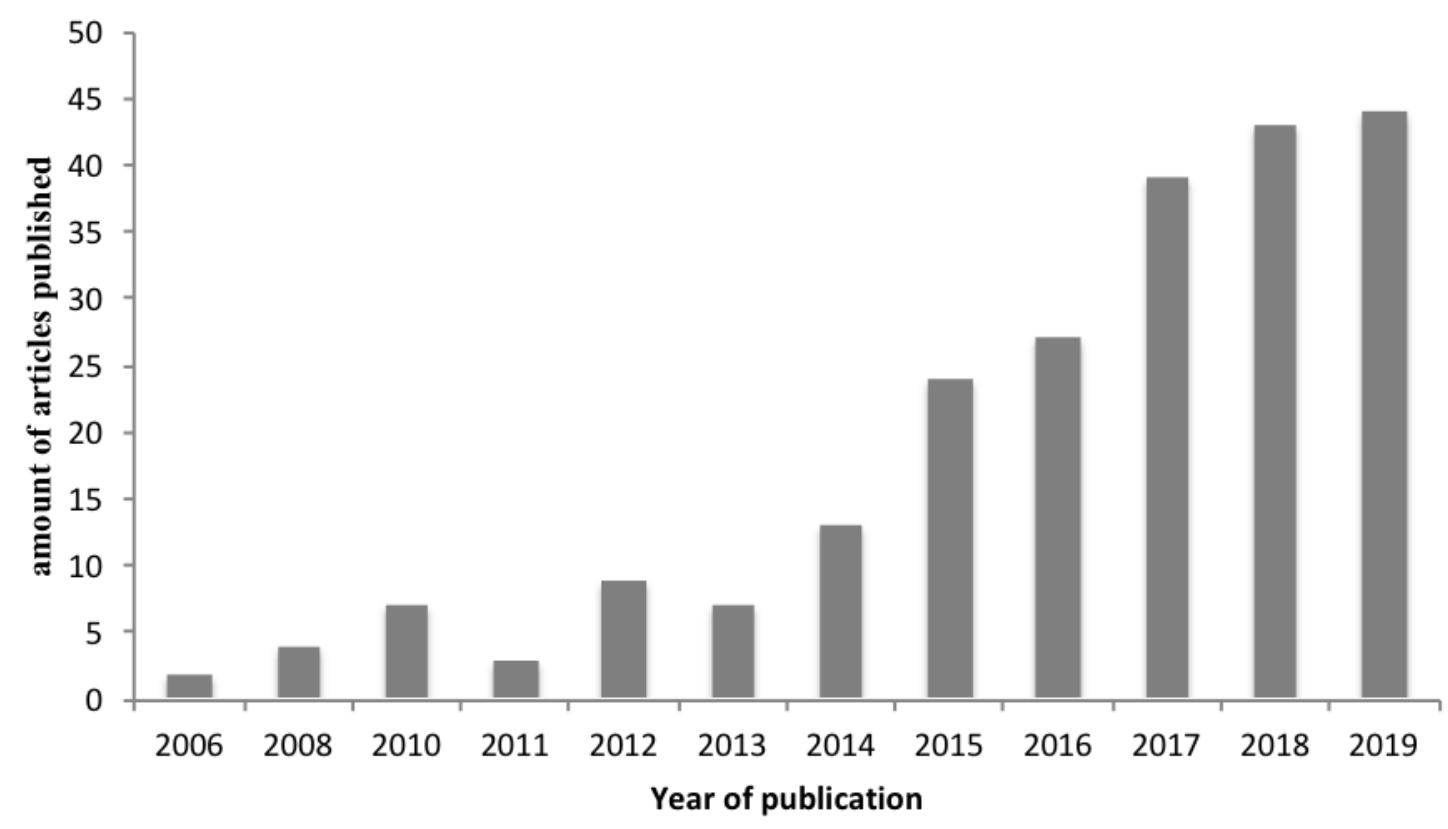

Figure 1 - Classification of publications by year. 
To assess the main axes used in research on the possible applications of sugarcane ash, the papers found were categorized according to the evaluated application. Most of them, approximately $60 \%$ of all articles evaluated, studied the application of ash from sugarcane bagasse in joint applications or as a substitute for Portland cement. The second most common theme was the use to replace components used in the manufacture of red ceramics, accounting for almost $20 \%$ of all articles. Some studies have also dealt with the use of by-product for soil treatment and stabilization and as adsorbent material, making up 7 and $3.2 \%$ of the papers, respectively. The other papers evaluated varied applications, with 1 or at most 2 papers per theme, not addressed in the discussions.

\section{Substitute in formulations of Portland cement concrete}

Ash from sugarcane bagasse is promising in the partial replacement of Portland cement, showing that this material may have pozzolanic activity. In several studies, the influence of different methods of processing sugarcane bagasse ash as to pozzolanic properties are observed (BAHURUDEEN; SANTHANAM, 2015).

Some studies have evaluated the replacement of Portland cement for sugarcane bagasse ash in the proportions of 10 to $30 \%$, together with rice husk ash. The resistance of mixtures increased by $5 \%$ after 90 days, compared to the reference sample, but when ash rates increased to 25 and $30 \%$, there was a reduction in the compressive strength. In relation to electrical resistivity, the replacement of $20 \%$ of Portland cement for sugarcane bagasse ash promotes a $159 \%$ increase in electrical resistivity with a 90-day cure time. (JOSHAGHANI; MOEINI, 2018).

A study carried out in 2018 investigated the potential of sugarcane ash to make concrete mixtures. The economic analysis showed that the incorporation of this by-product can reduce the total cost of 1 $\mathrm{m}^{3}$ of concrete by more than $40 \%$ compared to conventional concrete (SINGH et al., 2018).

Another study evaluated the substitution of fine aggregate with substitutions of 5 to $20 \%$ for ash, showing results very similar to pure cement. It shows that the best performance of the trace is with $20 \%$ ash from the sugarcane bagasse in relation to the reference concrete (FERNANDES et al., 2015).

Another study investigated the possibility of the combined use of agro- and industrial waste in the development of concrete. Characteristics of self-compacting concrete made from cement mixed with ash from sugarcane bagasse and common Portland cement were examined in an experimental program. The results of the tests indicated that the substitution for sugarcane bagasse in mixtures resulted in less fluidity and increased levels of sulfate (LE; SHEEN; LAM, 2018). Some results indicate that $10 \%$ of the mixture of sugarcane bagasse ash with cement is the ideal percentage to obtain efficient and, consequently, more ecological self-compacting concrete (KHATUN; SINGH; SHARMA, 2018).

An experimental study with sugarcane bagasse ash replacing cement in $5,10,15,20$, and $25 \%$, by mass, was carried out in common, light and self-compacting concretes. The mechanical properties, such as compressive strength, tensile strength, impact resistance, workability, water absorption, and ultrasonic pulse speed were performed on the samples. The results indicated improvements in strength and impact resistance at light weight, as well as durability and quality of cement with mass substitution at $5 \%$. The tests were carried out on fresh and hardened concrete.

The partial substitution of lightweight cement for ash improved the performance of lightweight concrete, more than other types of con-

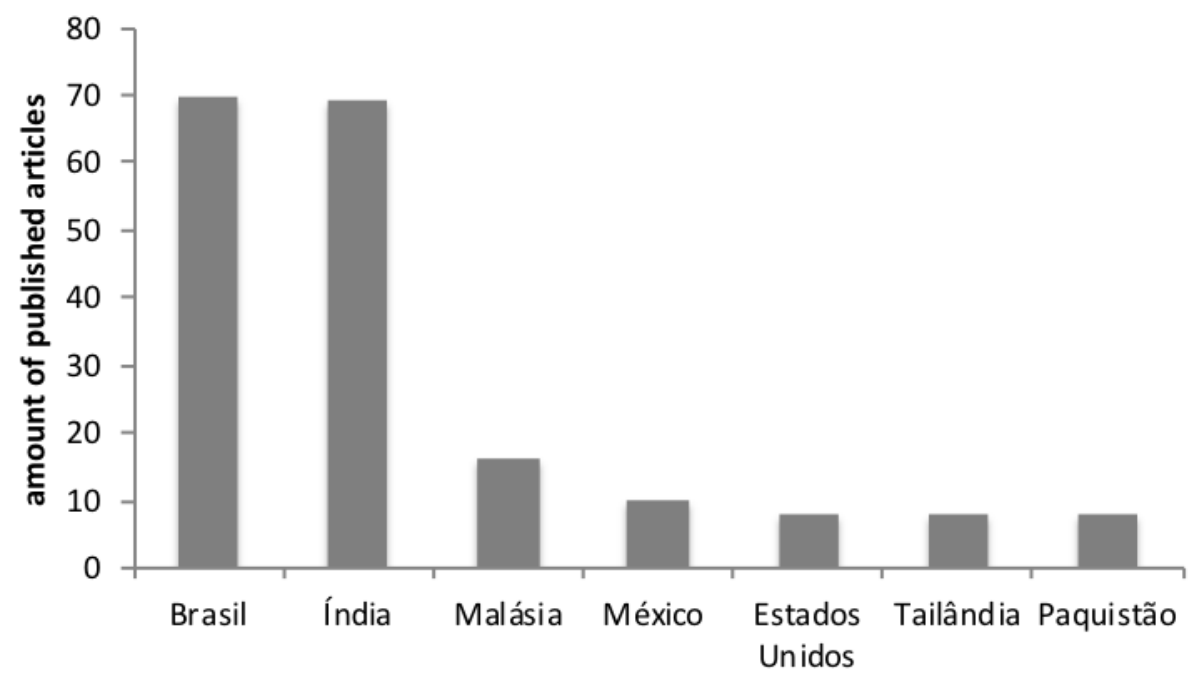

Country of publication

Figure 2 - Classification of publications according to the authors' country of affiliation. 
crete. With the addition of $5 \%$ of sugarcane bagasse ash, the strength properties of light cement improved. The demand for water increases in the same proportion of the added ash, due to the carbon content and the porous irregularities of ash. When replacing $5 \%$ of cement for ash, there was also an increase in durability and impact. Tests show that the optimal replacement of cement is in the percentages of $5 \%$ in normal weight (ZAREEI; AMERI; BAHRAMI, 2018).

The results obtained for partial replacement of Portland cement in concrete, in the proportions of $0,10,15$, and $20 \%$, by weight, also indicated that the strength of the concrete increased with the replacement of $15 \%$ of cement for ash from sugarcane bagasse sugar (SIREESHA; RAO; RAO, 2013).

\section{Red ceramic replacement}

The use of sugarcane bagasse ash in the production of ceramic tiles, containing up to $2.5 \%$ by weight of ash is a partial substitute for quartz. The test results, in terms of strength, flexion, apparent density, linear shrinkage and water absorption, indicated a great potential of ash for its industrial application (SCHETTINO; HOLANDA, 2015a).

A study developed in 2017 reported that the thermal conductivity of bricks is an important parameter, because it directly influences the heat loss of buildings and, therefore, increases energy consumption. Thermally burnt clay bricks were developed, incorporating agricultural residues (sugar cane bagasse ash and rice husk ash) on an industrial scale. It was observed that lighter bricks can be produced with agricultural by-product, which helps to reduce the cost and the overall weight of the structure (KAZMI et al., 2018).

Faria and Holanda (2013) studied the replacement of up to $20 \%$ of natural clay mass for sugarcane ash. The results in water absorption showed only a small variation $(22.76-27.40 \%)$. At $1,100^{\circ} \mathrm{C}$, there was a significant decrease in water absorption (14.45-19.50\%), caused by partial closure of open pores. For an addition of $20 \%$ of sugarcane bagasse ash, the ideal temperature is $1,100^{\circ} \mathrm{C}$. For burning without ash, the ideal temperature is between 700 and $1,100^{\circ} \mathrm{C}$.

For the replacement of up to $60 \%$ of natural clay for ash in the manufacturing process of tile, technological tests show that at temperatures up to $1,000^{\circ} \mathrm{C}$, the ash from sugarcane bagasse have little influence on the properties of clay, and after $1,200^{\circ} \mathrm{C}, \mathrm{X}$-ray diffraction data and thermal analysis showed that ash undergoes a sintering process and the formation of new phases. The addition of $60 \%$ of ash from sugarcane bagasse showed little resistance to flexion; on the other hand, the replacement of ash at $20 \%$ had very good results, staying within acceptable standard measures (SOUZA et al., 2011).

The flexural strength gradually decreased with the addition of sugarcane bagasse ash by-products, this result may be related to the porosity of pieces. The apparent density was essentially unchanged after the addition of sugarcane bagasse ash by-products. The incorporation of larger amounts of ash by-products tend to decrease the rate of densification of porcelain stoneware tiles. With the addition of sugarcane bagasse ash there was a variation in porosity, in which the permissible percentage is found in the substitution of $5 \%$ of the mass weight. The results showed that the replacement of the ceramic mass for sugarcane ash in $2.5 \%$ of the weight can be used as a partial substitute for stoneware porcelain, maintaining excellent technical properties. The flexural strength gradually decreased with the addition of sugarcane bagasse ash by-products, result which may be related to the porosity of pieces. The incorporation of larger amounts of ash by-products tend to decrease the rate of densification of porcelain stoneware tiles (SCHETTINO; HOLANDA, 2015b).

Another study evaluated the influence of adding ash from sugarcane bagasse on the performance in red ceramics as well. Two methods were evaluated: conventional sintering in an electric oven and microwave sintering. The results indicate that microwave sintering, when compared to sintering in an electric oven, promoted an increase in compressive strength and reduced adsorption water for the ceramic masses, probably due to the microstructure refinement. The addition of ash from sugarcane bagasse led to a reduction in the density of samples, especially those synthesized in the microwave (LYRA et al. 2019).

\section{Soil treatment and stabilization}

A major challenge for road contractors, as to the manufacture of paved roads, relies on expansive soils. Expansive soils undergo volume changes, depending on the humidity and weight of the mass that travel over soils or roads. Engineers are looking for a satisfactory, low-cost solution for the ash from sugarcane bagasse to solve this problem. In laboratory tests, percentages of ash and hydrated lime of up to $25 \%$ of the dry mass of the soil were used. Some tests developed show that the longer the curing time, the better the results obtained. (HASAN et al., 2016).

Very satisfactory results are obtained regarding the use of sugarcane bagasse ash in the construction of paved roads. The study evaluated the use of ash mixed with cement, replacing hydrated lime, in the proportions of 3,6, and $9 \%$, with the best mixture content found in the application of $9 \%$, with a cure of forty days (KHAN; KAMAL; HAROON, 2015).

Moreover, with the addition of $9 \%$ cement to the ash from sugarcane bagasse, there was a double increase in resistance to compression and maximum dry density, after 40 days of curing. The ash from sugarcane bagasse had very positive results, regarding environmental protection, appropriate waste management and the saving of raw materials. In short, the use of sugarcane ash is a great alternative in the application of road construction (KHAN; KAMAL; HAROON, 2015).

The tests show that the percentages of ash application vary, according to the application and the desired results for each application, being quite satisfactory and collaborating with the environment, and reducing financial resources (MALATHY et al., 2018).

The use of sugarcane bagasse ash was also evaluated in peat stabilization. Studies show that the partial replacement of peat stabilized 
at $20 \%$ of ash from sugarcane bagasse mass has very positive results. The pre-consolidation pressure increased with the curing period. In short, the results were quite significant, and the applications can be improved (ABU TALIB; YASUFUKU; ISHIKURA, 2015).

A study was carried out to evaluate the effects of adding sugarcane bagasse ash to the development of the strength of an expansive soil stabilized with lime. The results revealed that the addition of sugarcane bagasse increased the immediate, early, and late resistance of the stabilized soil (JAMES; PANDIAN, 2018).

Other studies have also been carried out with mixtures of different types of ash, such as rice husk ash, cattle manure ash, and sugar cane bagasse ash. The mixtures were used in weight percentages from 0 to $12.5 \%$ in soils. For each type of soil application, as well as its variables, such as microscopic properties and temperature, there is a need of collecting information, both of the soil variables and the desired purpose, so that it is possible to apply sugarcane bagasse ash and other organic materials to stabilize soils (JUN, 2011).

The natural, dry clay, after stabilization, increased the natural moisture. The results showed the optimum content of the substitution, in mass, of the ash with $7.5 \%$ with significant improvements in the natural humidity and volume (JUN, 2011).

In the case of its use for soil treatment, it is known that depending on the source of ash, it can present nutrients for the cultivation of annual plants. In Brazil, considering that there is a large area of oxisol, which unfortunately has little fertility and a lot of acidity, such by-product can be used for treatment and fertilization of these areas. Ash application raises the nutritional status of the soil to a sufficiently satisfactory level, guaranteeing adequate nutritional conditions for the growth and yield of most crops. The ash was effective in reducing acidity and improving soil fertility (FERREIRA; FAGERIAE; DIDONET, 2012).

It is known that sugarcane bagasse ash is also used for soil biofertilization, without protocol. This indicates the need to develop studies and create methods for the use of these by-products with a focus on the correct management and application in the soil without causing damage to the environment (XAVIER et al., 2019).

Other studies carried out by Lima (2011) evaluated the availability of Phosphorus (P) for soils treated with organic materials rich in silicon for the cultivation of sugarcane. Five compounds were studied, among which are sugarcane bagasse and sugarcane bagasse ash. The results showed a reduction in phosphorus (P) fixation by the soil but contributed to the absorption of this element by the sugarcane culture. The compounds containing sugarcane bagasse ash did not contribute to the increase in the levels of $\mathrm{Si}$ available in the soil.

\section{Adsorbent material}

A study undertaken in 2019 showed that silicon dioxide (SiO2) nanoparticles were synthesized via sol-gel using sugarcane bagasse ash as a source of silica. The results showed that this synthesis is a viable al- ternative method for obtaining silica xerogel (adsorbent material) using ash with a high content of impurities (FALK et al., 2019).

The activated carbon extracted from the ash from sugarcane bagasse at a temperature of $900^{\circ} \mathrm{C}$ was tested in the adsorption of lead $(\mathrm{Pb} 2+)$. In the process, the heating was $10^{\circ} \mathrm{C} / \mathrm{min}$, with a residence time of three hours. The lead adsorption test using sugarcane bagasse ash was dependent on $\mathrm{pH}$ and dosage. The tests showed that the maximum efficiency of $\mathrm{Pb} 2$ + was $87.3 \%$ (SALIHI et al., 2016a).

Activated, unburned and steam-activated coal has its properties compared to commercial coal. The study was carried out on two by-products of distilleries, namely, melanoidins and unburned carbon, both extracted in the distillery process. According to the studies, the two carbons are suitable for the adsorption of melanoidins with the addition of $25 \%$ pyridine (KAUSHIK et al., 2017).

The results of using the sugarcane bagasse ash as an adsorbent were very satisfactory, because the optimal removal efficiency was achieved at a $\mathrm{pH}$ of 6.0 . The ideal equilibrium time required for zinc adsorption was found in $180 \mathrm{~min}$. Given that the ash dosage increased, the number of active sites for adsorption of zinc ions also increased. The results showed an excellent efficiency in the removal of zinc, in the percentage of $89.7 \%$ obtained in a dose of $10 \mathrm{~g} / \mathrm{L}$ of the ash from the sugarcane bagasse. The ash was proved to be useful as an adsorbent for the removal of metal ions from aqueous solutions (SALIHI et al., 2016b).

The adsorption of melanoidins on both carbons (activated carbon from sugarcane bagasse ash and commercial activated carbon). Both carbons are suitable for the adsorption of melanoidins followed by desorption by $25 \%$ pyridine solution. Yield of melanoidins obtained from sugarcane ash was like that obtained with commercial activated carbon. Therefore, ash residues from sugar cane factories can be an alternative material to produce activated carbon with properties similar to commercial activated carbon (KAUSHIK et al., 2017).

\section{Final considerations}

The disposal of ash from sugarcane bagasse is a problem that has been gaining prominence in the world, considering it can cause, in addition to other problems, the contamination of soils and water. Thus, scholars are trying to find an efficient and legal way to dispose of this by-product.

Several applications can be considered to correctly dispose of this by-product, some with a higher incidence of studies, and others with only previous evaluations. Among the applications that are highly evaluated and in which this material has good efficiency, we can mention the use in Portland cement composites, either as a partial replacement for cement or fine aggregates, with the objective of increasing their mechanical resistance.

The second most studied topic was the replacement of clay in the ceramic industry. In this application, there are many variables, as the substitution of clay depends on some variables, from applied temperatures to the granulometry of the material. 
Besides that, the sugarcane bagasse ash can be efficiently used to stabilize soils with expansive properties or to correct some compounds in the soil, as fertilizing in this case.

In short, the application of sugarcane ash is not an easy task. There are many variables to be considered, such as the region, the cane specimen, the time the bagasse burns, the granulometry of ash, the curing temperature, the pozzolanic reaction with other substances, among others, which requires the researcher to pay special attention to its application.

The results of this paper show that it is possible to apply ash in several areas. On the other hand, there is no standard model to be followed. For each application, a study related to the properties of the available ash should be made.

\section{Contribution of authors:}

Duarte, G.W.: Conceptualization, Methodology, Project administration, Writing — Review \& Editing. Hobold, M.C.:Data curation, Formal analysis, Writing — original draft. Matos, A.H.: Data curation, Formal analysis, Writing — original draft. Silva, K.A.: Data curation, Formal analysis, Writing — original draft.

Duarte, G.W.: Data curation, Formal analysis, Writing - original draft.

\section{References}

ABU TALIB, M.K.; YASUFUKU, N.; ISHIKURA, R. Effects of sugarcane bagasse ash (SCBA) on the strength and compressibility of cement stabilized peat. Lowland Technology International, v. 17, n. 2, p. 73-82, 2015. https://doi. org/10.14247/lti.17.2_73

ALMEIDA, F.C.R.; SALES, A.; MORETTI, J.P.; MENDES, P.C.D. Sugarcane bagasse ash sand (SBAS): Brazilian agroindustrial by-product for use in mortar. Construction and Building Materials, v. 82, p. 31-38, 2015. https://doi. org/10.1016/j.conbuildmat.2015.02.039

ANDREÃO, P.; SULEIMAN, A.R.; CORDEIRO, G.C.; NEHDI, M.L. Beneficiation of sugarcane bagasse ash: pozzolanic activity and leaching behavior. Waste and Biomass Valorization, 2019. https://doi.org/10.1007/ s12649-019-00721-x

BAHURUDEEN, A.; SANTHANAM, M. Influence of different processing methods on the pozzolanic performance of sugarcane bagasse ash. Cement and Concrete Composites, v. 56, p. 32-45, 2015. https://doi.org/10.1016/j. cemconcomp.2014.11.002

BRAGAGNOLO, L.; FERRAZZO, S.; MUSCOPE, F.; KORF, E.; VARGAS, G.; ROSA, C.; PIAZZETTA, H.; TORMEN, A. Caracterização de resíduos da fundição de ferro e avaliação de possíveis aplicações na construção civil. Revista Brasileira de Ciências Ambientais (Online), n. 50, p. 61-77, 2018. https://doi.org/10.5327/Z2176-947820180390

CHOPPERLA, S.T.; YAMUNA, V.; BAHURUDEEN, A.; SANTHANAM, M.; GOPINATH, A. Durability of concrete with agro-waste: a local approach to sustainability. Green Materials, v. 7, n. 2, p. 84-96, 2019. https://doi.org/10.1680/ jgrma.18.00005

DAL MOLIN FILHO, R.G.; LONGHI, D.A.; DE SOUZA, R.C.T.; FERRER, M.M.; VANDERLEI, R.D.; PARAÍSO, P.R.; JORGE, L.M.M. Self-compacting mortar with sugarcane bagasse ash: development of a sustainable alternative for Brazilian civil construction. Environment Development and Sustainability, v. 21, p. 2125-2143, 2019. https://doi.org/10.1007/s10668-018-0127-x

FALK, G.S.; SHIHHE, G.P.; TEIXEIRA, L.B.; MORAES, E.G.; OLIVEIRA, A.P.N. Synthesis of silica nanoparticles from sugarcane ash and nanosilicon via magneiothermic reactions. Ceramics International, v. 45, n. 17, p. 21618 21624, 2019. https://doi.org/10.1016/j.ceramint.2019.07.157

FARIA, K.C.P.; HOLANDA, J.N.F. Thermal study of clay ceramic pastes containing sugarcane bagasse ash waste. Journal of Thermal Analysis and Calorimetry, v. 114, p. 27-32, 2013. https://doi.org/10.1007/s10973-012-2878-1
FERNANDES, S.E.; TASHIMA, M.M.; MORAES, J.C.B.; ISTUQUE, D.B.; FIORITI, C.F.; MELGES, J.L.P.; AKASAKI, J.L. Cinza de bagaço de cana-deaçúcar (CBC) como adição mineral em concretos para verificação de sua durabilidade. Matéria, v. 20, n. 4, p. 909-923, 2015. https://doi.org/10.1590/ S1517-707620150004.0096

FERREIRA, E.P.B.; FAGERIAE, N.K.; DIDONET, A.D. Chemical properties of an oxisol under organic management as influenced by application of sugarcane bagasse ash. Ciência Agronômica, v. 43, n. 2, p. 228-236, 2012. https://doi.org/10.1590/S1806-66902012000200004

HASAN, H.; DANG, L.; KHABBAZ, H.; FATAHI, B.; TERZAGHI, S. Remediation of Expansive Soils Using Agricultural Waste Bagasse Ash. Procedia Engineering, v. 143, p. 1368-1375, 2016. https://doi.org/10.1016/j. proeng.2016.06.161

IMRAN, M.; KHAN, A.R.A.; MEGERI, S.; SADIK, S. Study of hardness and tensile strength of Aluminium-7075 percentage varying reinforced with graphite and bagasse-ash composites. Resource-Efficient Technologies, v. 2, n. 2, p. 81-88, 2016. https://doi.org/10.1016/j.reffit.2016.06.007

JAMES, P.; PANDIAN, P.K. Bagasse Ash as an Auxiliary Additive to Lime Stabilization of an Expansive Soil: Strength and Microstructural Investigation. Advances in Civil Engineering, v. 2018, 2018. https://doi. org/10.1155/2018/9658639

JOSHAGHANI, A.; MOEINI, M.A. Evaluating the Effects of SugarcaneBagasse Ash and Rice-Husk Ash on the Mechanical and Durability Properties of Mortar. Journal of Materials in Civil Engineering, v. 30, n. 7, 2018. https:// doi.org/10.1061/(ASCE)MT.1943-5533.0002317

JOSHAGHANI, A.; RAMEZANIANPOUR, A.A.; ROSTAMI, H. Effect of incorporating Sugarcane Bagasse Ash (SCBA) in mortar to examine durability of sulfate attack. In: INTERNATIONAL CONFERENCE ON CONCRETE SUSTAINABILITY, 16., 2016. Proceedings... p. 576-596, 2016.

JUN, C. Survey of BMI distribution among university students aged 17 - 24 in Wenzhou. In: LECTURE NOTES IN ELECTRICAL ENGINEERING. Berlin: Springer, 2011. v. 132. p. 293-300. https://doi.org/10.1007/978-3-642-258992_40

KAUSHIK, A.; BASU, S.; SINGH, K.; BATRA, V.S.; BALAKRISHNAN, M. Activated carbon from sugarcane bagasse ash for melanoidins recovery. Journal of Environmental Management, v. 200, p. 29-34, 2017. https://doi. org/10.1016/j.jenvman.2017.05.060 
KAZMI, S.M.S.; MUNIR, M.J.; PATNAIKUNI, I.; WU, Y.-F.; FAWAD, U. Thermal performance anhancement of eco-friendly bricks incorporanting agro-wastes. Energy and Buildings, v. 158, p. 1117-1129, 2018. https://doi. org/10.1016/j.enbuild.2017.10.056

KHAN, S.; KAMAL, M.; HAROON, M. Potential of cement-treated sugar cane bagasse ash (SCBA) as highway construction material. Road and Transport Research, v. 24, n. 3, p. 35-43, 2015.

KHATUN, A.; SINGH, K.; SHARMA, R. Utilization of bagasse ash as a partial replacement of cement in self-compacting concrete. International Journal of Civil Engineering and Technology, v. 9, n. 7, p. 1078-1088, 2018.

LE, D.H.; SHEEN, Y.N.; LAM, Y.N. Fresh and hardened properties of self-compacting concrete with sugarcane bagasse ash-slag blended cement. Construction and Building Materials, v. 185, p. 138-147, 2018. https://doi. org/10.1016/j.conbuildmat.2018.07.029

LEITE, M.R.; ZANETTA, D.M.T; TREVISAN, I.B.; BURDMANN, E.A.; SANTOS, U.P. O trabalho no corte de cana-de-açúcar, riscos e efeitos na saúde: revisão da literatura. Revista de Saúde Pública, v. 52, p. 1-16, 2018. http:// dx.doi.org/10.11606/s1518-8787.2018052000138

LIMA, C.C. Availability of phosphorus for sugarcane in soil treated with silicon rich organic composts. Revista Brasileira de Engenharia Agricola e Ambiental, v. 15, n. 12, p. 1222-1227, 2011. http://dx.doi.org/10.1590/S141543662011001200002

LYRA, G.P.; SANTOS, V.; SANTIS, B.C.; RIVABEN, R.R.; FISCHER, C.; PALLONE, E.M.J.A.; ROSSIGNOLO, J.A. Reuse of sugarcane bagasse ash to produce a lightweight aggregate using microwave oven sintering. Construction and Building Materials, v. 222, p. 222-228, 2019.

MALATHY, J.; KUMAR, S.G.; SATISH, P.; ARUNACHALAM, S. Experimental investigation in developing a ternary blended cementitious binder produced from waste materials for pavements on soft soils. International Journal of Civil Engineering and Technology, v. 9, n. 5, p. 274-283, 2018.

MOHAN, M.; NARAYANASAMY, G.; CHANDRASEKAR, A. Effective utilization of sugarcane bagasse ash and marble dust in manufacturing of sustainable clay bricks. International Journal of Civil Engineering and Technology, v. 9, n. 11, p. 974-980, 2018.

REZA, S.M.S. Experimental studies of strength and cost analysis of mortar using bagasse waste obtained from sugarcane factory of Bangladesh. Journal of Environmental Treatment Techniques, v. 7, n. 3, p 300-305, 2019.

SACARDO, M.S. Estudo bibliométrico e epistemológico da produção científica em Educação Física na Região Centro-Oeste do Brasil. 257f. Thesis (PhD) Universidade Federal de São Carlos, São Carlos, 2012.

SALIHI, I.U.; KUTTY, S.R.M.; ISA, M.H.; AMINU, N. Process Optimization of Zinc Removal Using Microwave Incinerated Sugarcane Bagasse Ash
(MISCBA) Through Response Surface Methodology. Research Journal of Applied Sciences, Engineering and Technology, v. 12, n. 4, p. 395-401, $2016 \mathrm{a}$. http://doi.org/10.19026/rjaset.12.2378

SALIHI, I.U.; KUTTY, S.R.M.; ISA, M.H.; AMINU, N. Zinc removal from aqueous solution using novel adsorbent MISCBA. Journal of Water, Sanitation and Hygiene for Development, v. 6, n. 3, p. 377-388, 2016b. https://doi.org/10.2166/ washdev.2016.141

SANTHOSH, S.; JAGAN, P.; PRIYANGA, J. Analysis of mechanical properties on 3e-materials with blend concrete. International Journal of Civil Engineering and Technology, v. 9, n. 12, p. 666-677, 2018.

SCHETTINO, M.A.S.; HOLANDA, J.N.F. Characterization of Sugarcane Bagasse ash Waste for Its Use in Ceramic Floor Tile. Procedia Materials Science, v. 8, p. 190-196, 2015a. https://doi.org/10.1016/j.mspro.2015.04.063

SCHETTINO, M.A.S.; HOLANDA, J.N.F. Processing of porcelain stoneware tile using sugarcane bagasse ash waste. Processing and Application of Ceramics, v. 9, n. 1, p. 17-22, 2015 b.

SINGH, S.; RANSINCHING, G.D.; DEBBARMA, S.; KUMAR, P. Utilization of reclaimed asphalt pavement aggregates containing waste from Sugarcane Mill for production of concrete mixes. Journal of Cleaner Production, v. 174, p. 42-52, 2018. https://doi.org/10.1016/j.jclepro.2017.10.179

SIREESHA, G.; RAO, M.K.; RAO, P.K. An Experimental Study on Strength Properties of Concrete When Cement Is Partially Replaced With Sugar-Cane Bagasse Ash. IOSR Journal of Mechanical and Civil Engineering, v. 9, n. 3, p. 35-38, 2013.

SOUZA, A.E.; TEIXEIRA, S.R.; SANTOS, G.T.A.; COSTA, F.B.; LONGO, E. Reuse of sugarcane bagasse ash (SCBA) to produce ceramic materials. Journal of Environmental Management, v. 92, n. 10, p. 2774-2780, 2011. https://doi. org/10.1016/j.jenvman.2011.06.020

VARGAS, A.; LEPSCH, L.; PERES, A.; BRANCO, R. Análise do custo operacional da produção de ácido láctico e de Lactobacillus plantarum cct 0580 utilizando melaço de cana-de-açúcar. Revista Brasileira de Ciências Ambientais (Online), n. 46, p. 102-116, 2017. https://doi.org/10.5327/Z2176947820170168

XAVIER, A.A.P.; NICOLODELLI, G.; TADINI, A.M.; CORÁ, J.E.; VILLASBOAS, P.R.; MILORI, D.M.B.P. Evaluation of carbon content and humification index of soils under the application of by-products from sugarcane processing. Microchemical Journal, v. 149, p. 1-5, 2019. http://dx.doi.org/10.1016/j. microc.2019.104041

ZAREEI, S.A.; AMERI, F.; BAHRAMI, N. Microstructure, strength, and durability of eco-friendly concretes containing sugarcane bagasse ash. Construction and Building Materials, v. 184, p. 258-268, 2018. https://doi. org/10.1016/j.conbuildmat.2018.06.153 